\title{
Peningkatan Kesehatan Reproduksi Remaja melalui Posyandu Remaja Pashmina pada Era New Normal Covid -19
}

\author{
Maslikhah, Hilda Prajayanti, Ni'matul Ulya, Ida Baroroh \\ E mail: maslikhah_neysa@yahoo.co.id \\ D III Kebidanan, Akademi Kebidanan Harapan Ibu Pekalongan, Pekalongan \\ Jl. Sriwijaya No. 7 Pekalongan \\ Telp/Fax (0285)4416108
}

\begin{abstract}
Abstrak
Masa remaja merupakan masa storm and stress, karena remaja mengalami banyak tantangan baik dari diri mereka sendiri (biopsychosocial factors) ataupun lingkungan (environmental factors). Apabila remaja tidak memiliki kemampuan untuk menghadapi berbagai tantangan tersebut, mereka dapat berakhir pada berbagai masalah kesehatan yang begitu kompleks sebagai akibat dari perilaku berisiko yang mereka lakukan. Pembentukan Posyandu Remaja diharapkan dapat menjadi wadah untuk memfasilitasi remaja dalam memahami permasalahan kesehatan remaja, menemukan alternatif pemecahan masalah, membentuk kelompok dukungan remaja, memperluas jangkauan Puskesmas PKPR, terutama bagi remaja daerah yang memiliki keterbatasan akses. Tujuan pengabdian masyarakat ini adalah memberikan pendidikan kesehatan tentang Kesehatan Reproduksi Remaja melalui Posyandu Remaja "Pashmina" pada Era New Normal Covid 19. Metode pedidikan kesehatan yang dilakukan yaitu (1) Sosialisasi dan Perijinan, (2) Melakukan Affirmasi dan Pre Test (3) Melakukan Pendidikan kesehatan tentang Kesehatan Reproduksi Remaja. (4) Evaluasi hasil kegiatan pendidikan kesehatan dengan Post Test. Hasil kegiatan diharapkan adanya peningkatan dan pemahaman Kesehatan Reproduksi Remaja yang ditunjukkan dengan adanya peningkatan kesehatan reproduksi remaja dari hasil Pre Test (sebelum dilakukan Pendidikan Kesehatan) dengan Hasil Post Test (setelah dilakukan pendidikan kesehatan).
\end{abstract}

Kata kunci: kesehatan reproduksi remaja; posyandu remaja; era new normal covid 19.

\begin{abstract}
Adolescence is a period of storm and stress, because adolescents experience many challenges both from themselves (biopsychosocial factors) and the environment (environmental factors). If adolescents do not have the ability to face these challenges, they can end up with complex health problems as a result of their risky behavior. The establishment of the Youth Posyandu is expected to be a forum to facilitate adolescents in understanding adolescent health problems, find alternative solutions to problems, form youth support groups, expand the reach of the PKPR Health Center, especially for regional youth who have limited access. The purpose of this community service is to provide health education about Adolescent Reproductive Health through the "Pashmina" Youth Posyandu in the New Normal Covid 19 Era. The health education methods carried out are (1) Socialization and Licensing, (2) Affirmation and Pre Test (3) Conducting Health education on Adolescent Reproductive Health. (4) Evaluation of the results of health education activities with Post Test. The results of the activity are expected to increase and understand Adolescent Reproductive Health as indicated by an increase in adolescent reproductive health from the results of the Pre Test (before Health Education) and Post Test Results (after health education).
\end{abstract}

Keywords: adolescent reproductive healt; youth posyandu; new normal era covid-19 


\section{Pendahuluan}

Menurut WHO, remaja adalah penduduk dalam rentang usia 10-19 tahun. Menurut Peraturan Menteri Kesehatan RI Nomor 25 Tahun 2014, remaja adalah penduduk dalam rentang usia 10-18 tahun dan menurut badan kependudukan dan keluarga berencana (BKKBN) rentang usia remaja adalah 10-24 tahun dan belum menikah. Jumlah kelompok usia 10-19 tahun di Indonesia menurut Sensus Penduduk Tahun 2010 sebanyak 43,5 juta atau sekitar $18 \%$ dari jumlah penduduk. Didunia diperkirakan kelompok remaja berjumlah 1,2 milyar atau $18 \%$ daru jumlah penduduk dunia (WHO, 2014).

Masa remaja merupakan masa storm and stress, karena remaja mengalami banyak tantangan baik dari diri mereka sendiri (biopsychosocial factors) ataupun lingkungan (environmental factors). Apabila remaja tidak memiliki kemampuan untuk menghadapi berbagai tantangan tersebut, mereka dapat berakhir pada berbagai masalah kesehatan yang begitu kompleks sebagai akibat dari perilaku berisiko yang mereka lakukan.

Berdasarkan hasil Survei Kesehatan Berbasis Sekolah di Indonesia tahun 2015 (GSHS) dapat terlihat gambaran faktor risiko kesehatan pada pelajar usia 12-18 tahun (SMP dan SMA) secara nasional. Sebanyak 41,8\% laki-laki dan $4,1 \%$ perempuan mengaku pernah merokok, $32,82 \%$ diantara merokok pertama kali pada umur $\leq$ 13 tahun. Data yang sama juga menunjukkan $14,4 \%$ laki-laki dan $5,6 \%$ perempuan pernah mengkonsumsi alkohol, lalu juga didapatkan 2,6\% laki-laki pernah mengkonsumsi narkoba. Gambaran faktor risiko kesehatan lainnya adalah perilaku seksual di mana didapatkan $8,26 \%$ pelajar laki-laki dan $4,17 \%$ pelajar perempuan usia 12-18 tahun pernah melakukan hubungan seksual. (KEMENKES RI, 2018)

Kompleksnya permasalahan kesehatan pada remaja, tentunya memerlukan penanganan yang komprehensif dan terintegrasi yang melibatkan semua unsur dari lintas program dan sektor terkait. Kebijakan bidang kesehatan terkait pelayanan kesehatan remaja sebagaimana dimaksud Permenkes Nomor 25 Tahun 2014 ditujukan agar setiap anak memiliki kemampuan berperilaku hidup bersih dan sehat, memiliki keterampilan hidup sehat, dan keterampilan sosial yang baik sehingga dapat belajar, tumbuh dan berkembang secara harmonis dan optimal menjadi sumber daya manusia yang berkualitas.(BKKBN, 2011).

Pembentukan Posyandu Remaja diharapkan dapat menjadi wadah untuk memfasilitasi remaja dalam memahami permasalahan kesehatan remaja, menemukan alternatif pemecahan masalah, membentuk kelompok dukungan remaja, memperluas jangkauan Puskesmas PKPR, terutama bagi remaja daerah yang memiliki keterbatasan akses.

\section{Metode}

Lokasi pendidikan kesehatan yakni di Posyandu Remaja "Pashmina" Kelurahan Jenggot Kecamatan Pekalongan Selatan Kota Pekalongan. Peserta diberikan pemahaman terlebih dahulu melalui tujuan penyampaian materi pentingnya Kesehatan Reproduksi Remaja.

Metode yang diterapkan dalam pendidikan kesehatan pada kegiatan 
pengabdian kepada masyarakat yakni (1) Sosialisasi dan Perijinan, (2) Melakukan Afirmasi dan Pre Test (3) Melakukan Pendidikan kesehatan reproduksi remaja (4) Evaluasi hasil kegiatan pendidikan kesehatan dengan Post Test. Jumlah peserta dalam kegiatan sejumlah 42 remaja.

\section{Hasil dan Pembahasan}

Kegiatan Pengabdian kepada Masyarakat tentang Peningkatan Kesehatan Reproduksi Remaja Pendidikan kesehatan reproduksi remaja melalui Posyandu Remaja "Pashmina" pada Era New Normal Covid 19 bagi remaja di Posyandu Remaja "Pashmina" Kelurahan Jenggot Kecamatan Pekalongan Selatan Kota Pekalongan dapat meningkatkan pengetahuan dan pemahaman peserta yang sebelumnya tidak paham tentang materi Kesehatan Reproduksi Remaja. Dengan adanya pendidikan kesehatan, diharapkan para remaja dapat mengaplikasikan tentang materi kesehatan reproduksi remaja sehingga dapat menjaga kesehatan organ reproduksinya, pemenuhan gizi serta terhindar dari bahaya seks bebas, kehamilan diluar nikah dan faktor resiko kesehatan reproduksi remaja lainnya.

Hasil kegiatan Pengabdian kepada Masyarakat tentang Peningkatan Kesehatan Reproduksi Remaja Pendidikan kesehatan reproduksi remaja elalui Posyandu Remaja "Pashmina" pada Era New Normal Covid 19 diharapkan terjadi peningkatan dan pemahaman Kesehatan Reproduksi Remaja yang ditunjukkan dengan adanya peningkatan pengetahuan kesehatan reproduksi remaja dari hasil Pre Test (sebelum dilakukan Pendidikan Kesehatan) dengan Hasil Post Test (setelah dilakukan pendidikan kesehatan). (Grafik.1.1)

Grafik 1.1 Hasil Pre Test dan Post Test ( Evaluasi)

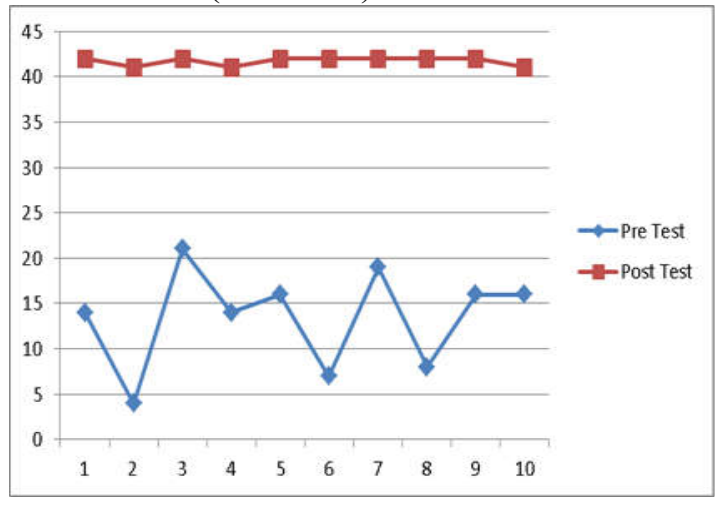

\section{Kesimpulan}

Kegiatan Pengabdian kepada Masyarakat tentang Peningkatan Kesehatan Reproduksi Remaja Pendidikan kesehatan reproduksi remaja elalui Posyandu Remaja "Pashmina" pada Era New Normal Covid 19 bagi remaja di Posyandu Remaja "Pashmina" Kelurahan Jenggot Kecamatan Pekalongan Selatan Kota Pekalongan ini dapat meningkatkan pengetahuan dan pemahaman peserta tentang pentingnya kesehatan reproduksi remaja sehingga dapat menjaga kesehatan organ reproduksinya, pemenuhan gizi serta terhindar dari bahaya seks bebas, kehamilan diluar nikah dan faktor resiko kesehatan reproduksi remaja lainnya.

Hasil Pre test tentang kesehatan reproduksi diperoleh hasil lebih dari separuh peserta yang belum memiliki pengetahuan yang benar tentang kesehatan reproduksi terlihat pertanyaan yang dijawab salah oleh peserta yaitu pertanyaan tentang dorongan seksual yang tinggi pada remaja, hormon yang mempengaruhi mentruasi, jenis infeksi menular seksual dan kebutuhan gizi pada remaja. 
Evaluasi kegiatan peningkatan kesehatan reproduksi remaja melalui posyandu remaja diperoleh jawaban yang benar dijawab oleh peserta yaitu terkiat definisi usia Remaja, cara menjaga organ reproduksi, definisi HIV, Jenis Infeksi menular seksual, pornografi dan kebutuhan gizi pada remaja.

\section{Daftar Pustaka}

[1] BKKBN, Kajian Profil Penduduk Remaja (10-24 tahun): Ada apa dengan remaja. Policy Brief Puslitbang kependudukanBKKBN. 2011.

[2] Kementerian Dasar, Riset Kementerian Dasar. Jakarta: Kemenkes RI, 2018. http://www.depkes.go.id/resou $\mathrm{rces} /$ download/infoterkini/mate ri rakorpop 20

18/Hasil\%20Riskesdas\%20201 8.pdf. (accessed Jan. 28, 2021).
[3] M. Rasyid, Pendidikan Seks. Semarang: Syiar Media Publishing, 2007.

[4] Kemenkes RI, Profil Kesehatan Indonesia tahun 2014. Jakarta: Kemenkes RI, 2015.

[5] M. Laila, Kesehatan dan Gizi Remaja. Kompasiana, 2018.

[6] WHO, Health for the World's Adolescents: A Second Chance in the Second Decade. Geneva, World Health Organization Departemen of Noncommunicable disease surveillance. 2014.

[7] A. Abu and N. Uhbiyati, Ilmu Pendidikan. Jakarta: Rineka Cipta, 2001. 